\title{
Safety and tolerability of lurbinectedin (PM01183) in patients with acute myeloid leukemia and myelodysplastic syndrome
}

\author{
Christopher B. Benton ${ }^{1}$, Kelly S. Chien ${ }^{2}$, Ayalew Tefferi ${ }^{5}$, Jose Rodriguez ${ }^{3}$, Farhad \\ Ravandi $^{1}$, Naval Daver ${ }^{1}$, Elias Jabbour ${ }^{1}$, Nitin Jain ${ }^{1}$, Yesid Alvarado ${ }^{1}$, Monica Kwari ${ }^{1}$, \\ Sherry Pierce ${ }^{1}$, Abhishek Maiti ${ }^{2}$, Marisa Hornbaker ${ }^{1}$, Margarida A. Santos ${ }^{4}$, Sara Martinez ${ }^{3}$, \\ Mariano Siguero ${ }^{3}$, Darci Zblewski ${ }^{5}$, Aref Al-Kali ${ }^{5}$, William J. Hogan ${ }^{5}$, Hagop Kantarjian ${ }^{1}$, \\ Animesh Pardanani ${ }^{5}$, and Guillermo Garcia-Manero ${ }^{1,}{ }^{*}$ \\ ${ }^{1}$ The University of Texas MD Anderson Cancer Center, Department of Leukemia, Houston, TX, \\ USA \\ ${ }^{2}$ The University of Texas MD Anderson Cancer Center, Division of Cancer Medicine, Houston, TX, \\ USA \\ ${ }^{3}$ PharmaMar, Madrid, Spain \\ ${ }^{4}$ The University of Texas Health Sciences Center, Department of Epigenetics and Molecular \\ Carcinogenesis, Houston, TX USA \\ ${ }^{5}$ Mayo Clinic, Rochester, MN USA
}

\begin{abstract}
Trabectedin is an FDA-approved DNA minor groove binder (MGB) that has activity against translocation-associated sarcomas. Lurbinectedin is a next-generation MGB with pre-clinical activity against myeloid leukemia cells. A dose-finding phase 1 clinical trial was performed in patients with acute myeloid leukemia (AML) and myelodysplastic syndrome (MDS) with further assessment of safety and tolerability. Forty-two patients with relapsed/refractory AML/MDS received lurbinectedin administered as a 1 -hour intravenous infusion in a $3+3$ study design. Two dosing schedules were used: $3.5 \mathrm{mg}, 5 \mathrm{mg}, 7 \mathrm{mg}$, or $6 \mathrm{mg}$ on days 1 and 8 or $2 \mathrm{mg}, 3 \mathrm{mg}, 1 \mathrm{mg}$, or $1.5 \mathrm{mg}$ for 3 consecutive days on days 1 to 3 . Three patients experienced dose-limiting toxicities (DLTs) of rhabdomyolysis (grade 4), hyperbilirubinemia (grade 3), and oral herpes (grade 3) with the days 1 and 8 schedule. Otherwise, adverse events (AEs) mainly consisted of gastrointestinal manifestations $(n=11)$, febrile neutropenia/infections $(n=4)$, pulmonary toxicity $(n=2)$, and renal failure $(\mathrm{n}=2)$. The most common laboratory abnormalities observed were an increase in creatinine (93\%) and anemia, neutropenia, and thrombocytopenia (100\%). Overall, 33 of 42 patients (79\%) had reduction in blasts in peripheral blood or bone marrow. One patient achieved a partial response and two patients a morphologic leukemia-free state. Most ( $\mathrm{n}=30,71 \%)$ were discontinued due to progressive disease. Early deaths occurred from disease-related causes that were not attributable to lurbinectedin. Four patients with a chromosome 11q21-23 abnormality had significantly greater
\end{abstract}

\footnotetext{
*Corresponding Author: Guillermo Garcia-Manero, MD, Department of Leukemia, The University of Texas MD Anderson Cancer Center, 1515 Holcombe Blvd., Unit 428, Houston, TX 77030, ggarciam@ @mdanderson.org.

Conflicts of Interest: None to disclose.
} 
bone marrow blast reduction than those without such abnormality, with decrease of $31 \pm 14 \%(n=4)$ vs. $8 \pm 8 \%(\mathrm{n}=16)$, respectively $(P=0.04)$. Overall, lurbinectedin was safe and tolerated using the schedules and dose levels tested. While no sustained remissions were observed, single-agent lurbinectedin was transiently leukemia suppressive for some patients.

\section{Keywords}

myelodysplastic syndromes; acute myeloid leukemia; lurbinectedin; PM01183; minor groove binder; phase 1 clinical trial

\section{Introduction}

Trabectedin is a DNA minor groove binder (MGB) that was FDA-approved in 2015 after showing an increased median progression-free survival compared to dacarbazine in patients with metastatic or recurrent leiomyosarcoma or liposarcoma(1). A known myelosuppresive agent, significant neutropenia is a side effect of treatment with trabectedin(2). A recent study showed that trabectedin induced apoptosis and inhibition of growth of hematopoietic progenitor cells in patients with juvenile myelomonocytic leukemia and chronic myelomonocytic leukemia (CMML)(3).

Lurbinectedin (PM01183) is a next-generation minor groove binder structurally similar to trabectedin except for the $\mathrm{C}$ subunit, which contains a tetrahydro $\beta$-carboline rather than the additional tetrahydroisoquinoline of trabectedin $(4,5)$. It has highly potent in vitro and in vivo antitumor activity by covalently modifying guanines in the DNA minor groove, causing DNA double-strand breaks, arrest in the S-phase of mitosis, and cell death by apoptosis(4). It also exerts an effect on the tumor microenvironment by decreasing tumor-associated macrophages and tumor vasculature(6). Lurbinectedin inhibits genes of the RhoGTPase pathway (involved in signaling events such as actin-cytoskeleton organization and cell motility) in monocytes and myeloid leukemic cells, and it inhibits myeloid-derived suppressor cells in vitro and in vivo(6,7). There have been four phase 1 trials with lurbinectedin in solid tumors(8-11) investigating the recommended dose of lurbinectedin administration with promising results in combination with another agent in small cell lung cancer and soft tissue sarcoma. To study the safety and clinical activity of lurbinectedin, we performed a two-institution phase 1 clinical trial in patients with advanced, relapsed/ refractory acute myeloid leukemia (AML) or myelodysplastic syndrome (MDS). Given the clinical heterogeneity of AML with different responses to therapy based on cytogenetics and other characteristics, we also examined the impact of chromosome abnormalities and prior therapy with hypomethylating agents.

\section{Methods}

\section{Clinical trial}

The study was conducted at two institutions, The University of Texas MD Anderson Cancer Center (MDACC; Houston, TX) and Mayo Clinic (MC; Rochester, MN), and was approved by respective Institutional Review Boards. The clinical trial was conducted in accordance 
with the ethical principles that have their origin in the World Medical Association Declaration of Helsinki, and all patients provided informed written consent. This study is registered at ClinicalTrials.gov (NCT01314599). Patients 18 years or older with a diagnosis of advanced, relapsed/refractory AML (non-APL) and MDS who were untreated or had relapsed/refractory disease irrespective of the number of prior lines of therapy were eligible and treated on study. Eligible patients had adequate hepatic, renal, and cardiac function and an Eastern Cooperative Oncology Group (ECOG) performance status of 0 to 2. Patients with uncontrolled infection, human immunodeficiency virus, cardiac and neurological disorders, or those who were pregnant were ineligible.

\section{Dosing and administration}

Lurbinectedin was supplied by PharmaMar S.A. (Colemnar Viejo, Madrid, Spain) as a $1 \mathrm{mg}$ / vial and $4 \mathrm{mg} / \mathrm{vial}$ lyophilized powder concentrate for solution for infusion. It was reconstituted with sterile water and diluted with $5 \%$ glucose solution or $0.9 \%$ sodium chloride solution. In the initial cohort, lurbinectedin was administered as a 1-hour infusion on day 1 and day 8 of a 21-day cycle. Due to the dose-limiting toxicities observed with the days 1 and 8 administration, this schedule was considered unfeasible and changed to a three consecutive day administration, which was considered more adequate for treating leukemia. Subsequently, it was administered as a 1-hour intravenous infusion on days 1-3 of a 21-day cycle. Dose escalation followed a standard 3+3 design. Doses of lurbinectedin tested were $3.5,5,7$, and $6 \mathrm{mg}$ for the day 1 and day 8 schedule, and 2, 3,1, and $1.5 \mathrm{mg}$ for the days 1-3 schedule. According to response and toxicity profile, patients could receive re-induction and/or consolidation therapies with the same schedule as the treatment phase. Re-induction with lurbinectedin was allowed if $\geq 10 \%$ of bone marrow or peripheral blasts was present on day 14 to 21 following treatment. Consolidation therapy with lurbinectedin was administered if bone marrow blasts were $\mathbf{5 \%}$ after induction or re-induction and had to be given within 1 to 2 weeks after hematological recovery but within 50 days after the last dose of lurbinectedin. For patients with blasts between 5 to $10 \%$, lurbinectedin administration was repeated every 7 to 14 days until remission or leukemic blasts $\geq 10 \%$. Patients received standard antiemetic prophylaxis prior to each infusion and antibiotic prophylaxis as indicated. The maximum tolerated dose (MTD) was the lowest dose level at which more than one evaluable patient experienced a DLT during induction, and the recommend dose (RD) was the highest dose level explored below the MTD with less than one third of patients experiencing DLT.

\section{Study assessments}

Patients had bone marrow evaluation at baseline, prior to the start of each new cycle, and the end-of-treatment visit 30 days after discontinuation of treatment. Treatment was administered until disease progression, unacceptable toxicity, development of concurrent severe illnesses, treatment delay of more than two weeks, more than two dose reductions, or patient refusal or non-compliance. Safety was evaluated in all patients who received at least one lurbinectedin infusion by assessment of AEs, clinical laboratory test results, physical examinations and vital signs. AEs were recorded and coded with the Medical Dictionary for Regulatory Activities (MedDRA) v.14.1, and both AEs and DLTs were graded according to the National Cancer Institute - Common Terminology Criteria for Adverse Events (NCI- 
CTCAE) v4. Any clinically relevant NCI-CTCAE grade $\geq 3$ were reassessed every 2 to 3 days until recovery to grade $\leq 1$ or baseline. DLTs were defined as AEs and laboratory abnormalities related to the study drug causing grade 4 ALT or AST increase or grade 3 ALT or AST increase > 2 weeks, grade $\geq 3 \mathrm{CPK}$ increase, prolonged pancytopenia with hypocellular bone marrow $>50$ days from start of therapy, any non-hematologicla toxicity of grade $\geq 3$ considered unrelated to underlying disease or tumor lysis syndrome, grade $\geq 3$ asthenia, non-clinically relevant isolated biochemical abnormalities, omission of drug administration on 2 days of induction due to AEs suspected to be related to lurbinectedin, and delay in administration of post-induction therapy $>2$ weeks due to any nonhematological AE suspected to be related to lurbinectedin. After treatment discontinuation, patients were followed every 4 weeks until resolution of toxicities. Patients who discontinued treatment without progression were followed every 4 weeks for disease status until disease progression, start of other antitumor therapy, death, or the pre-defined end-ofstudy date, whichever occurred first.

\section{Exploratory and statistical analysis}

Peripheral blood and bone marrow samples were collected prior to treatment. Patients at MDACC had molecular diagnostics as a part of routine workup that included flow cytometry, karyotyping and mutation analysis using next-generation sequencing for leukemia-associated genes. Patients were summarized by dose level with descriptive statistics. Response rates were categorized according to criteria corresponding to leukemia subtype(12), and included morphologic leukemia-free state (MLFS). Responses were characterized using descriptive statistics and overall response rate included complete (CR), partial responses (PR), and MLFS. Comparison of data was performed using a two-sided ttest, association evaluated with Pearson correlation, and statistical analysis performed using GraphPad Prism v7.03 (GraphPad Software, La Jolla, CA, USA).

\section{Results}

Patients

A total of 45 patients were enrolled at two investigational sites in the U.S., and 42 patients were treated between May 2011 and July 2015. Patient characteristics are shown in Table 1. Overall, using the day 1 and day 8 schedule $(\mathrm{n}=24), 3$ patients were treated at the $3.5 \mathrm{mg}$ dose level, 4 at $5 \mathrm{mg}, 11$ at $7 \mathrm{mg}$, and 6 at $6 \mathrm{mg}$ Among patients on the days 1-3 schedule $(\mathrm{n}=18), 5$ were treated at the $2 \mathrm{mg}$ dose level, 6 at $3 \mathrm{mg}, 4$ at $1 \mathrm{mg}$, and 3 at $1.5 \mathrm{mg}$.

All 24 treated patients on the days 1 and 8 schedule received the induction phase, three patients $(13 \%)$ received the re-induction phase, and one patient $(4 \%)$ received the consolidation phase with a median of one phase (range, 1-3 phases). All 18 treated patients on the days 1-3 schedule received the induction phase, and nine patients (50\%) received the re-induction phase with a median of one phase (range, 1-3 phases).

\section{Toxicities}

DLT was observed at two of the dose levels tested and occurred in 3 out of 16 evaluabale patients (19\%) on the days 1 and 8 schedule (Table 2). At the highest dose level of 
lurbinectedin $7 \mathrm{mg}$ administered on days 1 and 8, 2 out of 11 treated patients (18\%) had DLTs of grade 3 hyperbilirubinemia and grade 3 oral herpes infection. In the next lower dose level of $6 \mathrm{mg}$ administered on days 1 and 8, 1 of 6 treated patients (17\%) developed DLT with grade 4 rhabdomyolysis. Due to the dose-limiting toxicities and high dropout rate from early disease progression, it was decided not to expand the $6 \mathrm{mg}$ cohort, and a protocol amendment was made to change the drug schedule from days 1 and 8 to a days 1-3 infusion schedule at $2 \mathrm{mg}, 3 \mathrm{mg}, 1 \mathrm{mg}$, or $1.5 \mathrm{mg}$ with dose escalation according to a $3+3$ study design. No DLTs were observed at any dose level with the days 1-3 schedule; hence, the MTD and RD could not be determined for the schedule of PM01183 as a 1-hour intravenous infusion on days $1-3$.

\section{Safety}

All 42 treated patients were evaluable for safety. Table 3 summarizes all adverse events observed during both schedules. The majority of adverse events included gastrointestinal manifestations $(n=11)$, febrile neutropenia and infections $(n=4)$, pulmonary toxicity $(n=2)$, and renal failure $(n=2)$. Nausea and/or vomiting $(n=9)$, diarrhea $(n=2)$, cellulitis $(n=2)$, and acute renal failure $(n=2)$ were the most common toxicities. Seven of $16(44 \%)$ of the reported adverse events on the day 1 and day 8 schedule occurred in the patients who received $7 \mathrm{mg}$ of lurbinectedin, and 13 of 14 (93\%) of the reported adverse events on the day 1 to day 3 schedule occurred in the patients who received $3 \mathrm{mg}$ of lurbinectedin. The biochemical and hematological abnormalities observed during both schedules are also delineated, with the most common being an increase in creatinine (93\%) and anemia, neutropenia, and thrombocytopenia (100\%), respectively.

All 42 patients who received lurbinectedin discontinued treatment prior to the study cutoff. The primary reasons for discontinuation in both schedules were progressive disease $(n=12$ for day 1 and $8, n=11$ for days 1 to 3 ) and death ( $\mathrm{n}=6$ for day 1 and $8, \mathrm{n}=4$ for days 1 to 3 ). There were no treatment delays during the study due to lurbinectedin-related reasons, but one patient receiving lurbinectedin from days 1 to 3 had the day 3 infusion delayed by one day due to reasons unrelated to treatment.

\section{Clinical activity and outcomes}

Pre- and post-treatment data on peripheral and marrow blasts were available for all patients. Out of 42 patients, 33 (79\%) experienced reduction in bone marrow blasts and/or peripheral blood blasts at nadir. Twenty-three patients (55\% of all patients) had $>50 \%$ reduction in blast percentage in either the $\mathrm{PB}$ or $\mathrm{BM}$, and of these, $5(12 \%)$ had $>50 \%$ reduction in both $\mathrm{PB}$ and BM with lurbinectedin $1 \mathrm{mg}(\mathrm{n}=1), 2 \mathrm{mg}(\mathrm{n}=1), 5 \mathrm{mg}(\mathrm{n}=2)$, and $7 \mathrm{mg}(\mathrm{n}=1)$.

A total of 34 patients (17 in each dosing schedule) were evaluable for efficacy. At best response, 2 patients (5\%) reached a MLFS and 1 patient (2\%) experienced PR with a progression-free survival (PFS) of 1.3 to 3.2 months (Table 4). Most patients ( $\mathrm{n}=13$ in day 1 and 8 schedule, $n=16$ in days 1 to 3 schedule) had relapsed or refractory disease. Early deaths were attributed to disease-related causes, including relapse/progression $(\mathrm{n}=7,17 \%)$, sepsis $(n=5,12 \%)$, and cardiopulmonary failure $(n=2,5 \%)$. 


\section{Exploratory analysis}

Twenty patients had bone marrow results analyzable for responses in the context of chromosomal aberrations and prior therapy. Patients with abnormalities at chromosome 11q21-23 ( $\mathrm{n}=4)$ had significantly greater bone marrow blast reduction than those without this abnormality $(\mathrm{n}=16)$, with reductions of $31 \pm 14 \%$ vs. $8 \pm 8 \%$, respectively ( $P=0.04$; Figure 1A). There was no difference in blast change with respect to exposure to prior hypomethylating agent therapy $(P=0.78)$. Among patients with complex cytogenetics, 5 out of $9(56 \%)$ had blast percentage reductions, similar to patients without complex cytogenetics, where 5 out of 11 (45\%) had reductions (Figure 1B). The number of cytogenetic abnormalities did not correlate with the change in BM blast percentage ( $P=0.45$, Figure 1C), or with the change in absolute PB blasts $(P=0.12$, Figure 1D). No other associations between blast reductions and prior therapy or chromosomal changes were found among these patients.

\section{Discussion}

The phase 1 trial reported here found lurbinectedin to be safe and tolerated in patients with advanced AML/MDS at up to $3 \mathrm{mg}$ when dosed on days $1-3$, and up to $5 \mathrm{mg}$ when dosed on day 1 and day 8 . One instance of grade 4 toxicity was experienced which was rhabdomyolysis, in a patient given $6 \mathrm{mg}$ on day 1 and day 8 . The dose finding results of this study in patients with leukemia were generally consistent with a previous study of lurbinectedin in advanced solid tumors where the final RD was $7 \mathrm{mg}$ given once, or approximately $4 \mathrm{mg} / \mathrm{m}^{2}(8)$. Lurbinectedin was generally well tolerated with nausea/vomiting the primary toxicity observed. All of the patients received antiemetics with steroids and 5$\mathrm{HT}_{3}$ antagonists via intravenous infusions with additional nausea prophylaxis as needed, though this regimen might need to be increased in the future. Previous phase 1 trials of lurbinectedin with and without cytotoxic chemotherapy showed myelosuppression to be the main toxicity with no reports of rhabdomyolysis(8-11). In the current study, there were two cases of cellulitis and one case of febrile neutropenia.

Patients on study had very high-risk AML/MDS characteristics. Most were heavily pretreated (up to 6 prior lines of therapy and median 3), and among 32 patients for whom data was available, 20 had high-risk karyotypic abnormalities ( 16 had complex cytogenetics, 3 had -7/7q-, and 1 had inversion 3). Lurbinectedin had transient anti-leukemia effect in 79\% of patients, and no sustained response was observed. Three patients had objective response at post-treatment assessment (ORR=7\%), and no CR's were observed. Interestingly, 1 of the patients who responded developed AML from CMML, though 2 other patients with transformed CMML did not respond to treatment. No statistically significant differences with respect to prior treatment or karyotype were found except among four patients with abnormalities at chromosome 11q21-23. Although patient numbers were small, these patients had greater reduction in marrow blast percentage compared to other patients. $K M T 2 A(M L L)$, located at 11q23, is recurrently disrupted in leukemia, and therapeutic strategies for these subsets are needed(13). Lurbinectedin has previously been shown to inactivate the EWS-FLI1 transcription factor, associated with $\mathrm{t}(11 ; 22)(\mathrm{q} 24 ; \mathrm{q} 12)$ in Ewing's sarcoma, potentially with redistribution of the fusion protein to the nucleolus(14). MGBs 
could also have efficacy against cells with specific structurally unstable chromosomal alterations. In a previous study testing tallimustine, also a MGB(15), four out of 26 patients (15\%) had responses with 2 CRs and 2 with hematologic improvement(16). One of the four responding patients had a karyotype with $\operatorname{del}(11)(\mathrm{q} 13 ; \mathrm{q} 23)$. It is possible that MGBs find a role in AML/MDS in the setting of specific genetic or chromosomal abnormalities, such as aberrant chromosome 11q.

Lurbinectedin was relatively safe and tolerated at most dose levels tested. Single-agent lurbinectedin was transiently leukemia suppressive for a majority of patients, though all patients progressed. It was ineffective at inducing complete remissions in advanced AML/MDS patients. There is a possibility lurbinectedin, targeting myeloid-derived suppressor cells, may be effective in patients with less advanced disease. Its use in lower doses in patients, such as those with lower-risk MDS, has yet to be evaluated. It did appear to induce greater bone marrow blast reduction in patients with abnormalities at chromosome 11q21-23; however, these patients also progressed. Previous work has demonstrated that trabectedin-resistant cells had overexpression of the insulin growth factor receptor 1 (IGFR1R)(17), and concomitant use of anti-IGFR1 agents with trabectedin greatly increased cytotoxic effects(18). Lurbinectedin and trabectedin have both been used in combination with other agents for solid tumors $(9,10)$. Rational combinations and alternative dosing/ sequencing strategies of MGBs in this class might also be considered for hematologic malignancies. The use of lurbinectedin in patients with lower-risk MDS/AML, in individuals with MLL-rearranged leukemias, or in combination with other cytotoxic and targeted therapies (such as anti-IGFR1 agents) warrants further consideration.

\section{References}

1. Demetri GD, von Mehren M, Jones RL, Hensley ML, Schuetze SM, Staddon A, et al. Efficacy and Safety of Trabectedin or Dacarbazine for Metastatic Liposarcoma or Leiomyosarcoma After Failure of Conventional Chemotherapy: Results of a Phase III Randomized Multicenter Clinical Trial. J Clin Oncol. 2016;34(8):786-93. [PubMed: 26371143]

2. Blay JY, Leahy MG, Nguyen BB, Patel SR, Hohenberger P, Santoro A, et al. Randomised phase III trial of trabectedin versus doxorubicin-based chemotherapy as first-line therapy in translocationrelated sarcomas. Eur J Cancer. 2014;50(6):1137-47. [PubMed: 24512981]

3. Romano M, Della Porta MG, Galli A, Panini N, Licandro SA, Bello E, et al. Antitumour activity of trabectedin in myelodysplastic/myeloproliferative neoplasms. Br J Cancer. 2017;116(3):335-43. [PubMed: 28072764]

4. Soares DG, Machado MS, Rocca CJ, Poindessous V, Ouaret D, Sarasin A, et al. Trabectedin and its C subunit modified analogue PM01183 attenuate nucleotide excision repair and show activity toward platinum-resistant cells. Mol Cancer Ther. 2011;10(8):1481-9. [PubMed: 21622731]

5. Leal JF, Martinez-Diez M, Garcia-Hernandez V, Moneo V, Domingo A, Bueren-Calabuig JA, et al. PM01183, a new DNA minor groove covalent binder with potent in vitro and in vivo anti-tumour activity. Br J Pharmacol. 2010;161(5):1099-110. [PubMed: 20977459]

6. Belgiovine C, Bello E, Liguori M, Craparotta I, Mannarino L, Paracchini L, et al. Lurbinectedin reduces tumour-associated macrophages and the inflammatory tumour microenvironment in preclinical models. Br J Cancer. 2017;117(5):628-38. [PubMed: 28683469]

7. Kuroda H, Mabuchi S, Kozasa K, Yokoi E, Matsumoto Y, Komura N, et al. PM01183 inhibits myeloid-derived suppressor cells in vitro and in vivo. Immunotherapy. 2017;9(10):805-17. [PubMed: 28877631] 
8. Elez ME, Tabernero J, Geary D, Macarulla T, Kang SP, Kahatt C, et al. First-in-human phase I study of Lurbinectedin (PM01183) in patients with advanced solid tumors. Clin Cancer Res. 2014;20(8): 2205-14. [PubMed: 24563480]

9. Paz-Ares L, Forster M, Boni V, Szyldergemajn S, Corral J, Turnbull S, et al. Phase I clinical and pharmacokinetic study of PM01183 (a tetrahydroisoquinoline, Lurbinectedin) in combination with gemcitabine in patients with advanced solid tumors. Invest New Drugs. 2017;35(2):198-206. [PubMed: 27873130]

10. Calvo E, Moreno V, Flynn M, Holgado E, Olmedo ME, Lopez Criado MP, et al. Antitumor activity of lurbinectedin (PM01183) and doxorubicin in relapsed small-cell lung cancer: results from a phase I study. Ann Oncol. 2017;28(10):2559-66. [PubMed: 28961837]

11. Jimeno A, Sharma MR, Szyldergemajn S, Gore L, Geary D, Diamond JR, et al. Phase I study of lurbinectedin, a synthetic tetrahydroisoquinoline that inhibits activated transcription, induces DNA single- and double-strand breaks, on a weekly $\times 2$ every-3-week schedule. Invest New Drugs. 2017;35(4):471-7. [PubMed: 28105566]

12. Cheson BD, Bennett JM, Kopecky KJ, Buchner T, Willman CL, Estey EH, et al. Revised recommendations of the International Working Group for Diagnosis, Standardization of Response Criteria, Treatment Outcomes, and Reporting Standards for Therapeutic Trials in Acute Myeloid Leukemia. J Clin Oncol. 2003;21(24):4642-9. [PubMed: 14673054]

13. Liang K, Volk AG, Haug JS, Marshall SA, Woodfin AR, Bartom ET, et al. Therapeutic Targeting of MLL Degradation Pathways in MLL-Rearranged Leukemia. Cell. 2017;168(1-2):59-72 e13. [PubMed: 28065413]

14. Harlow ML, Maloney N, Roland J, Guillen Navarro MJ, Easton MK, Kitchen-Goosen SM, et al. Lurbinectedin Inactivates the Ewing Sarcoma Oncoprotein EWS-FLI1 by Redistributing It within the Nucleus. Cancer Res. 2016;76(22):6657-68. [PubMed: 27697767]

15. Cai X, Gray PJ, Jr., Von Hoff DD. DNA minor groove binders: back in the groove. Cancer Treat Rev. 2009;35(5):437-50. [PubMed: 19328629]

16. Beran M, Jeha S, O'Brien S, Estey E, Vitek L, Zurlo MG, et al. Tallimustine, an effective antileukemic agent in a severe combined immunodeficient mouse model of adult myelogenous leukemia, induces remissions in a phase I study. Clin Cancer Res. 1997;3(12 Pt 1):2377-84. [PubMed: 9815637]

17. Manara MC, Perdichizzi S, Serra M, Pierini R, Benini S, Hattinger CM, et al. The molecular mechanisms responsible for resistance to ET-743 (Trabectidin; Yondelis) in the Ewing's sarcoma cell line, TC-71. Int J Oncol. 2005;27(6):1605-16. [PubMed: 16273217]

18. Amaral AT, Garofalo C, Frapolli R, Manara MC, Mancarella C, Uboldi S, et al. Trabectedin efficacy in Ewing sarcoma is greatly increased by combination with anti-IGF signaling agents. Clin Cancer Res. 2015;21(6):1373-82. [PubMed: 25609059] 
A

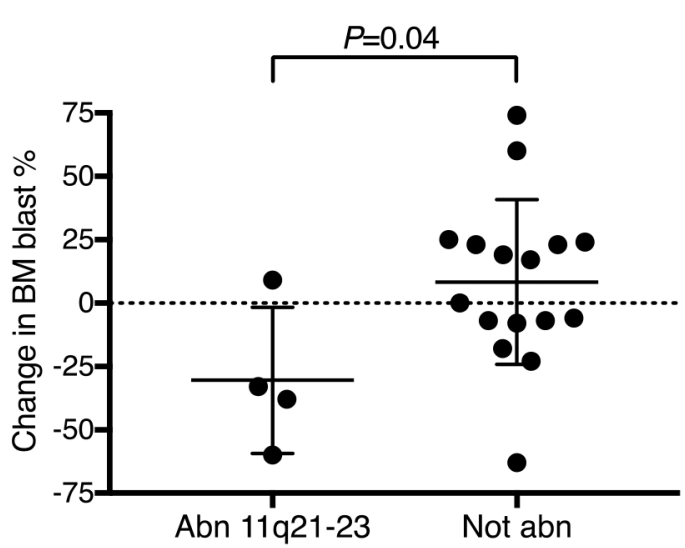

C

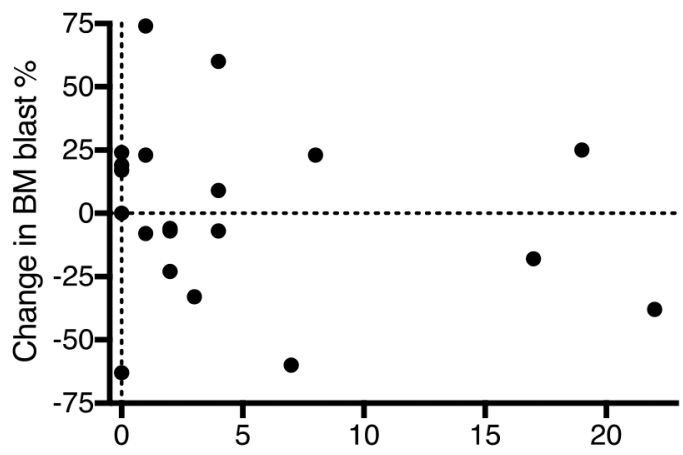

No. cytogenetic abnormalities
B

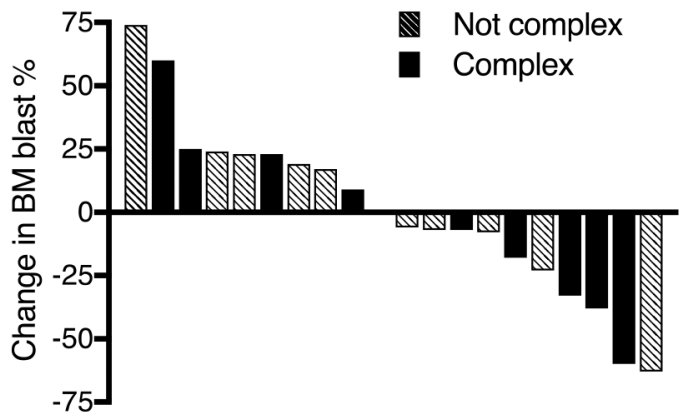

D

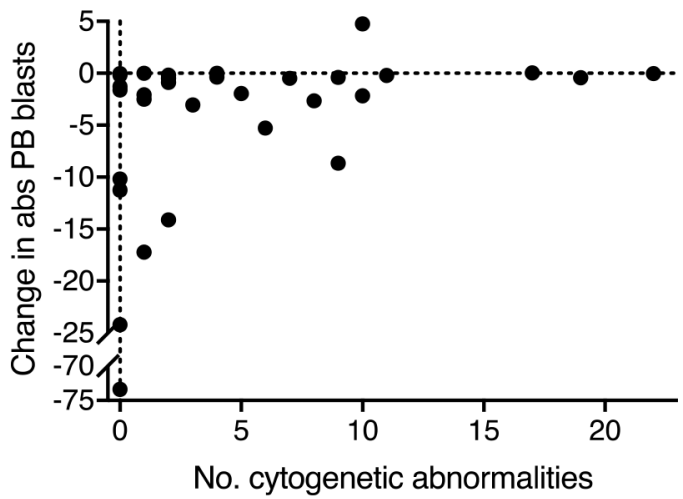

Figure 1. Bone Marrow Blast Response Based on Chromosomal Abnormalities.

A) Change in BM blasts with lurbinectedin treatment among patients with vs. without chromosome 11q21-23 abnormalities. B) Waterfall plot of change in marrow blasts among patients with and without complex cytogenetics. C) Change in BM blasts with lurbinectedin administration by number of cytogenetic abnormalities. D) Change in PB blasts with lurbinectedin treatment by number of cytogenetic abnormalities. 
Table 1.

Patient Characteristics at Study Entry.

\begin{tabular}{|c|c|c|}
\hline & Day 1 and 8 Schedule $(n=26)$ & Day 1 to 3 Schedule $(n=19)$ \\
\hline \multicolumn{3}{|l|}{ Gender } \\
\hline Male & $14(53.8 \%)$ & $13(68.4 \%)$ \\
\hline Female & $12(46.2 \%)$ & $6(31.6 \%)$ \\
\hline Median Age (Range) [years] & $63.5(20-78)$ & $63.0(22-80)$ \\
\hline \multicolumn{3}{|l|}{ ECOG Performance Status } \\
\hline $\mathbf{0}$ & $4(16.0 \%)$ & $3(15.8 \%)$ \\
\hline 1 & $13(52.0 \%)$ & $12(63.2 \%)$ \\
\hline 2 & $8(32.0 \%)$ & $4(21.1 \%)$ \\
\hline \multicolumn{3}{|l|}{ Laboratory Values, NCI-CTCAE Grade } \\
\hline Anemia, 1-4 & $26(100 \%)$ & $19(100 \%)$ \\
\hline Leukopenia, 1-4 & $13(50.0 \%)$ & $13(68.4 \%)$ \\
\hline Lymphopenia, 1-4 & $14(53.8 \%)$ & $12(63.2 \%)$ \\
\hline Neutropenia, 1-4 & $20(76.9 \%)$ & $15(78.9 \%)$ \\
\hline Thrombocytopenia, 1-4 & $26(100 \%)$ & $19(100 \%)$ \\
\hline Median Bone Marrow Blast Percentage (Range) & $65(8-98)$ & $65(15-85)$ \\
\hline Median Peripheral Myeloid Blast Percentage (Range) & $42(0-98)$ & $36.5(0-97)$ \\
\hline \multicolumn{3}{|l|}{ Diagnosis } \\
\hline Primary AML & $18(69.2 \%)$ & $12(63.2 \%)$ \\
\hline Secondary AML & $6(23.1 \%)$ & $7(36.8 \%)$ \\
\hline Blast Phase of Chronic Myeloid Leukemia & $2(7.7 \%)$ & 0 \\
\hline \multicolumn{3}{|l|}{ Cytogenetics [n/number tested] } \\
\hline Diploid & $3 / 16(18.8 \%)$ & $5 / 16(31.3 \%)$ \\
\hline$-5 / 5 q-$ & $2 / 16(12.5 \%)$ & $4 / 16(25.0 \%)$ \\
\hline$-7 / 7 q-$ & $4 / 16(25.0 \%)$ & $5 / 16(31.3 \%)$ \\
\hline $\mathbf{t}(\mathbf{8} ; 21)$ & $1 / 19(5.3 \%)$ & $1 / 16(6.3 \%)$ \\
\hline 11q abnormalities & $3 / 16(18.8 \%)$ & $4 / 16(25.0 \%)$ \\
\hline Complex & $7 / 16(43.8 \%)$ & $9 / 16(56.3 \%)$ \\
\hline \multicolumn{3}{|l|}{ Mutational Analysis [n/number tested] } \\
\hline FLT3 & $1 / 15(6.7 \%)$ & $2 / 17(11.8 \%)$ \\
\hline IDH1 & $1 / 9(11.1 \%)$ & $3 / 16(18.8 \%)$ \\
\hline IDH2 & $1 / 9(11.1 \%)$ & $2 / 16(12.5 \%)$ \\
\hline JAK2 & $0 / 4$ & $0 / 13$ \\
\hline NPM1 & $1 / 13(7.7 \%)$ & $1 / 17(5.9 \%)$ \\
\hline RAS & $3 / 15(20.0 \%)$ & $1 / 17(5.9 \%)$ \\
\hline TP53 & $0 / 2$ & $2 / 12(16.7 \%)$ \\
\hline Time from Diagnosis to First Infusion (Range) [months] & $10.0(0.2-52.0)$ & $11.6(2.8-69.7)$ \\
\hline
\end{tabular}




\begin{tabular}{|l|l|l|}
\hline & Day $\mathbf{1}$ and 8 Schedule $(\mathbf{n}=\mathbf{2 6})$ & Day $\mathbf{1}$ to 3 Schedule $(\mathbf{n}=\mathbf{1 9})$ \\
\hline Median Number of Prior Lines of Therapy (Range) & $2.0(0-5)$ & $3.0(0-9)$ \\
\hline Allogeneic Stem Cell Transplantation & $5(19.2 \%)$ & $6(31.6 \%)$ \\
\hline
\end{tabular}

Data shown are n (\%) of patients, except for median (range). 
Table 2.

Dose Escalation Scheme and Dose-Limiting Toxicity.

\begin{tabular}{|l|l|l|l|}
\hline Lurbinectedin Dose & $\begin{array}{l}\text { Number of Evaluable Patients/Number of } \\
\text { Treated Patients }\end{array}$ & Number of Patients with DLTs & DLT \\
\hline $3.5 \mathrm{mg} \mathrm{D} 1,8$ & $3 / 3$ & 0 & --- \\
\hline $5.0 \mathrm{mg} \mathrm{D} 1,8$ & $3 / 4$ & 0 & --- \\
\hline $7.0 \mathrm{mg} \mathrm{D} 1,8$ & $7 / 11$ & $2(18.2 \%)$ & $\begin{array}{l}\text { Hyperbilirubinemia }(\text { grade } 3, \mathrm{n}=1) \\
\text { Oral herpes (grade 3, } \mathrm{n}=1)\end{array}$ \\
\hline $6.0 \mathrm{mg} \mathrm{D} 1,8$ & $3 / 6$ & $1(16.7 \%)$ & Rhabdomyolysis (grade $4, \mathrm{n}=1)$ \\
\hline $2.0 \mathrm{mg} \mathrm{D} 1-3$ & $4 / 5$ & 0 & --- \\
\hline $3.0 \mathrm{mg} \mathrm{D} 1-3$ & $2 / 6$ & 0 & --- \\
\hline $1.0 \mathrm{mg} \mathrm{D} 1-3$ & $3 / 4$ & 0 & --- \\
\hline $1.5 \mathrm{mg} \mathrm{D} 1-3$ & $2 / 3$ & 0 & --- \\
\hline
\end{tabular}

Data shown are $\mathrm{n}(\%)$ of patients. 
Table 3.

Drug-Related Adverse Events.

\begin{tabular}{|c|c|c|c|c|}
\hline & \multicolumn{3}{|c|}{ NCI-CTCAE Grade } & \multirow[t]{2}{*}{ Dosage Levels } \\
\hline & 1-2 & 3 & 4 & \\
\hline \multicolumn{5}{|l|}{ Adverse Events } \\
\hline Candidiasis & 1 & & & $3 \mathrm{mg}(\mathrm{n}=1)$ \\
\hline Cellulitis & & 2 & & $3.5 \mathrm{mg}(\mathrm{n}=1), 7 \mathrm{mg}(\mathrm{n}=1)$ \\
\hline Decreased Appetite & 1 & & & $7 \mathrm{mg}(\mathrm{n}=1)$ \\
\hline Dehydration & & 1 & & $3 \mathrm{mg}(\mathrm{n}=1)$ \\
\hline Diarrhea & 2 & & & $6 \mathrm{mg}(\mathrm{n}=1), 3 \mathrm{mg}(\mathrm{n}=1)$ \\
\hline Dyspnea & 1 & & & $7 \mathrm{mg}(\mathrm{n}=1)$ \\
\hline Epistaxis & 1 & & & $3 \mathrm{mg}(\mathrm{n}=1)$ \\
\hline Febrile Neutropenia & & 1 & & $3.5 \mathrm{mg}(\mathrm{n}=1)$ \\
\hline Hyperbilirubinemia & & 1 & & $7 \mathrm{mg}(\mathrm{n}=1)$ \\
\hline Hyperhidrosis & 1 & & & $7 \mathrm{mg}(\mathrm{n}=1)$ \\
\hline Hypoalbuminemia & & 1 & & $3 \mathrm{mg}(\mathrm{n}=1)$ \\
\hline Nausea/ Vomiting & 7 & 2 & & $3.5 \mathrm{mg}(\mathrm{n}=2), 5 \mathrm{mg}(\mathrm{n}=1), 6 \mathrm{mg}(\mathrm{n}=1), 2 \mathrm{mg}(\mathrm{n}=1), 3 \mathrm{mg}(\mathrm{n}=4)$ \\
\hline Oral Herpes & & 1 & & $7 \mathrm{mg}(\mathrm{n}=1)$ \\
\hline Peripheral Edema & & 1 & & $3 \mathrm{mg}(\mathrm{n}=1)$ \\
\hline Pulmonary Edema & & & 1 & $7 \mathrm{mg}(\mathrm{n}=1)$ \\
\hline QTc Prolongation & & 1 & & $6 \mathrm{mg}(\mathrm{n}=1)$ \\
\hline Renal Failure & & 1 & 1 & $3 \mathrm{mg}(\mathrm{n}=2)$ \\
\hline Rhabdomyolysis & & & 1 & $6 \mathrm{mg}(\mathrm{n}=1)$ \\
\hline Tumor Lysis Syndrome & & & 1 & $3 \mathrm{mg}(\mathrm{n}=1)$ \\
\hline \multicolumn{5}{|l|}{ Biochemical Abnormalities $^{a}$} \\
\hline ALT Increase & 28 & 4 & & $\begin{array}{l}3.5 \mathrm{mg}(\mathrm{n}=2), 5 \mathrm{mg}(\mathrm{n}=2), 7 \mathrm{mg}(\mathrm{n}=8), 6 \mathrm{mg}(\mathrm{n}=5), 2 \mathrm{mg}(\mathrm{n}=3), 3 \mathrm{mg}(\mathrm{n}=6), 1 \mathrm{mg} \\
(\mathrm{n}=3), 1.5 \mathrm{mg}(\mathrm{n}=3)\end{array}$ \\
\hline Alkaline Phosphatase Increase & 25 & & & $\begin{array}{l}3.5 \mathrm{mg}(\mathrm{n}=1), 5 \mathrm{mg}(\mathrm{n}=3), 7 \mathrm{mg}(\mathrm{n}=4), 6 \mathrm{mg}(\mathrm{n}=6), 2 \mathrm{mg}(\mathrm{n}=4), 3 \mathrm{mg}(\mathrm{n}=4), 1 \mathrm{mg} \\
(\mathrm{n}=2), 1.5 \mathrm{mg}(\mathrm{n}=1)\end{array}$ \\
\hline AST Increase & 25 & 2 & 1 & $\begin{array}{l}3.5 \mathrm{mg}(\mathrm{n}=3), 5 \mathrm{mg}(\mathrm{n}=2), 7 \mathrm{mg}(\mathrm{n}=7), 6 \mathrm{mg}(\mathrm{n}=5), 2 \mathrm{mg}(\mathrm{n}=2), 3 \mathrm{mg}(\mathrm{n}=6), 1 \mathrm{mg} \\
(\mathrm{n}=2), 1.5 \mathrm{mg}(\mathrm{n}=1)\end{array}$ \\
\hline Bilirubin Increase & 12 & 5 & 1 & $\begin{array}{l}5 \mathrm{mg}(\mathrm{n}=1), 7 \mathrm{mg}(\mathrm{n}=4), 6 \mathrm{mg}(\mathrm{n}=5), 2 \mathrm{mg}(\mathrm{n}=1), 3 \mathrm{mg}(\mathrm{n}=4), 1 \mathrm{mg}(\mathrm{n}=1), 1.5 \mathrm{mg} \\
(\mathrm{n}=2)\end{array}$ \\
\hline CPK Increase & 6 & & 4 & $3.5 \mathrm{mg}(\mathrm{n}=1), 5 \mathrm{mg}(\mathrm{n}=1), 7 \mathrm{mg}(\mathrm{n}=2), 6 \mathrm{mg}(\mathrm{n}=4), 3 \mathrm{mg}(\mathrm{n}=2)$ \\
\hline Creatinine Increase & 33 & 6 & & $\begin{array}{l}3.5 \mathrm{mg}(\mathrm{n}=3), 5 \mathrm{mg}(\mathrm{n}=3), 7 \mathrm{mg}(\mathrm{n}=11), 6 \mathrm{mg}(\mathrm{n}=5), 2 \mathrm{mg}(\mathrm{n}=4), 3 \mathrm{mg}(\mathrm{n}=6), 1 \mathrm{mg} \\
(\mathrm{n}=3), 1.5 \mathrm{mg}(\mathrm{n}=4)\end{array}$ \\
\hline \multicolumn{5}{|l|}{ Hematological Abnormalities $^{a}$} \\
\hline Anemia & & 42 & & $\begin{array}{l}3.5 \mathrm{mg}(\mathrm{n}=3), 5 \mathrm{mg}(\mathrm{n}=4), 7 \mathrm{mg}(\mathrm{n}=11), 6 \mathrm{mg}(\mathrm{n}=6), 2 \mathrm{mg}(\mathrm{n}=5), 3 \mathrm{mg}(\mathrm{n}=6), 1 \mathrm{mg} \\
(\mathrm{n}=4), 1.5 \mathrm{mg}(\mathrm{n}=3)\end{array}$ \\
\hline Leukopenia & 1 & 3 & 36 & $\begin{array}{l}3.5 \mathrm{mg}(\mathrm{n}=3), 5 \mathrm{mg}(\mathrm{n}=4), 7 \mathrm{mg}(\mathrm{n}=11), 6 \mathrm{mg}(\mathrm{n}=5), 2 \mathrm{mg}(\mathrm{n}=4), 3 \mathrm{mg}(\mathrm{n}=6), 1 \mathrm{mg} \\
(\mathrm{n}=4), 1.5 \mathrm{mg}(\mathrm{n}=3)\end{array}$ \\
\hline Lymphocytosis & 5 & & & $5 \mathrm{mg}(\mathrm{n}=1), 7 \mathrm{mg}(\mathrm{n}=1), 6 \mathrm{mg}(\mathrm{n}=1), 2 \mathrm{mg}(\mathrm{n}=1), 3 \mathrm{mg}(\mathrm{n}=1)$ \\
\hline
\end{tabular}

Hematol Oncol. Author manuscript; available in PMC 2020 February 01. 


\begin{tabular}{|l|l|l|l|l|}
\hline & \multicolumn{3}{|l|}{ NCI-CTCAE Grade } & Dosage Levels \\
\hline & $\mathbf{1 - 2}$ & $\mathbf{3}$ & $\mathbf{4}$ & \\
\hline Lymphopenia & 4 & 11 & 26 & $\begin{array}{l}3.5 \mathrm{mg}(\mathrm{n}=3), 5 \mathrm{mg}(\mathrm{n}=4), 7 \mathrm{mg}(\mathrm{n}=11), 6 \mathrm{mg}(\mathrm{n}=5), 2 \mathrm{mg}(\mathrm{n}=5), 3 \mathrm{mg}(\mathrm{n}=6), 1 \mathrm{mg} \\
(\mathrm{n}=4), 1.5 \mathrm{mg}(\mathrm{n}=3)\end{array}$ \\
\hline Neutropenia & 1 & 1 & 40 & $\begin{array}{l}3.5 \mathrm{mg}(\mathrm{n}=3), 5 \mathrm{mg}(\mathrm{n}=4), 7 \mathrm{mg}(\mathrm{n}=11), 6 \mathrm{mg}(\mathrm{n}=6), 2 \mathrm{mg}(\mathrm{n}=5), 3 \mathrm{mg}(\mathrm{n}=6), 1 \mathrm{mg} \\
(\mathrm{n}=4), 1.5 \mathrm{mg}(\mathrm{n}=3)\end{array}$ \\
\hline Thrombocytopenia & & 1 & 41 & $\begin{array}{l}3.5 \mathrm{mg}(\mathrm{n}=3), 5 \mathrm{mg}(\mathrm{n}=4), 7 \mathrm{mg}(\mathrm{n}=11), 6 \mathrm{mg}(\mathrm{n}=6), 2 \mathrm{mg}(\mathrm{n}=5), 3 \mathrm{mg}(\mathrm{n}=6), 1 \mathrm{mg} \\
(\mathrm{n}=4), 1.5 \mathrm{mg}(\mathrm{n}=3)\end{array}$ \\
\hline
\end{tabular}

Data shown are $\mathrm{n}(\%)$ of patients.

${ }^{a}$ Based on total patients with laboratory data available. 
Table 4.

Characteristics of Responding Patients.

\begin{tabular}{|l|l|l|l|}
\hline & Patient 1 & Patient 2 & Patient 3 \\
\hline Age & 63 & 25 & 77 \\
\hline Gender & Male & Female & Female \\
\hline ECOG Performance Status & 2 & 1 & 1 \\
\hline Diagnosis & Secondary AML from CMML & Primary AML & $\begin{array}{l}\text { Secondary AML from } \\
\text { MDS }\end{array}$ \\
\hline Cytogenetics & 46, XY,del(6)(q13q25)[2]; 47,sl,+21[2]; 46,XY[16] & Unknown & 46,XX[20] \\
\hline $\begin{array}{l}\text { Prior Lines of Therapy (Last } \\
\text { Therapy) }\end{array}$ & 4 (cytarabine) & 5 (clofarabine) & 2 (clinical trial) \\
\hline Dose of Lurbinectedin & 5 mg (D1, D8) & 7 mg (D1, D8) & 2 mg (D1-D3) \\
\hline PFS [months] & 2.0 & 1.3 & 3.2 \\
\hline Reason for Discontinuation & Progressive disease & Progressive disease & $\begin{array}{l}\text { Decreased performance } \\
\text { status after infectious } \\
\text { complication }\end{array}$ \\
\hline
\end{tabular}

